\title{
УДК: 657.331.21:616.9
}

\section{ОСОБЛИВОСТІ ОБЛІКУ РОЗРАХУНКІВ 3 ОПЛАТИ ПРАЦ}

\section{В УМОВАХ ПАНДЕМІЇ}

Л. В. ГУЦАЛЕНКО, доктор економічних наук, професор, професор кафедри обліку та оподаткування

Національний університет біоресурсів і природокористування Украӥни

ORCID: 0000-0001-5181-8652

E-mail: Gutsalenko.l.v@nubip.edu.ua

М.С. НІКОЛЕНКО, студентка економічного факультету, спеціальності «Облік і оподаткування»

Національний університет біоресурсів і природокористування Украӥни

ORCID: 0000-0001-9709-0812

E-mail: Maria.680@ukr.net

Анотащія. У статті розглянуто прогноз Міжнародної організаиї праці щодо рівня безробіття спричиненого пандемією COVID-19. Проаналізовано реальні показники безробіття в Украӥні в розрізі місяців протягом запровадженого карантину у 2020 році та порівняно ці дані з показниками за аналогічний період 2019 року. Вказано основні можливі способи збереження робочих місиь із дотриманням карантинних заходів, а також мінімізацією витрат на оплату праці та підтриманням рівня продуктивності праці. Охарактеризовано кожен з перелічених у статті способів. Наголошено на особливостях їх документального оформлення на підприємствах. Досліджено ведення обліку розрахунків з оплати прачі за різних умов упродовж карантину. Зокрема, проведено детальне вивчення оплати різних видів відпусток під час карантину, їх документальне оформлення та умови надання. Особливо приділена увага наданню безоплатної відпустки, ї̈ тривалість та особливості продовження. Розглянуто питання нарахування Єдиного сочіального внеску при наданні працівникові відпустки без збереження заробітної плати. Порівняно особливості оплати працівників переведених на неповний робочий час та працівників переведених на позмінну роботу на час карантину. Вивчено особливості оплати пращі понаднормово відпращьованих годин за погодинної форми оплати праці. Проаналізовано оплату прачі ід час дистанційної роботи та режим, за яким може здійснюватися виконання посадових обов'язків. Розглянуто можливість надання працівникам інших виплат під час дистанційної роботи. Виокремлено можливі виплати працівникам, а також особливості нарахування та сплату податків під час простою. Здійснено аналіз поглядів вчених на дане питання. Розглянуто досвід інших краӥн, щьодо питання оплати праці в умовах пандемї. Надано пропозиції, щзодо можливих заходів та деталізащії обліку 
розрахунків з оплати прачі в період карантину. Запропоновано форму внутрішньогосподарської звітності для контролю використаних $i$ невикористаних днів відпусток. Зроблено висновки щэодо викладеної в статті інформації.

Ключові слова: облік, оплата прачі, робочий час, оплачувана відпустка, безоплатна відпустка, дистаниійна робота.

Актуальність. Пандемія COVID-19 стала нелегким випробуванням для підприємців, оскільки, постало завдання беззбиткового ведення підприємницької діяльності з дотриманням карантинних заходів задля недопущення поширення хвороби. Ці заходи негативно впливають на прибутковість підприємств. Як результат, власники бізнесу шукають шляхи зменшення витрат. Найчастіше таким шляхом слугує скорочення робочих місць. Такий метод негативно впливає на рівень зайнятості населення країни. Тому потрібно використовувати та шукати альтернативні методи підтримання діяльності бізнесу, зокрема, ефективно використовувати робочу силу, водночас правильно здійснювати розрахунки 3 оплати праці, щоби не зважаючи на особливі умови, працівники були справедливо винагородженні за результатами їх роботи, а підприємство мало можливості вести подальшу господарську діяльність.

Аналіз останніх досліджень та публікацій. Дослідженню питання організації роботи працівників за різних умов була приділена увага таких вчених як: Я. В. Свічкарьової, Б. А. Андрушкіна, О. Б. Погайдак, А. А. Власова, Л. П. Гаращенко, О. Г. Середи, Я. В. Сімутіної та інших.

Питання конкретно оплати праці вивчали: А. Е. Ачкасов, О. А. Боярова Ф. Ф. Бутинець, Н.Н.Грабова， Л.В.Гуцаленко, Р. І. Криницький, Н. П. Кузик, В. С. Лень, С. В. Мних, Г. В. Нашкерська, В. В. Сопко, Л. К. Сук, К. В. Шевчук.

3 огляду на ситуацію, що склалася та не зменшуючи вагомості проведених досліджень, дане питання потребує подальшого вивчення.

Мета. Метою статті є дослідження особливостей розрахунків з оплати праці працівників за різних умов їхньої роботи в період карантинних обмежень. 
Матеріали та методи дослідження. Під час дослідження були використані такі загальнонаукові методи як аналіз, синтез, порівняння та узагальнення.

Результати дослідження та їх обговорення. На початку 2020 року Міжнародна організація праці розглядала три варіанти впливу пандемії на зайнятість населення в світі. Найгірший варіант полягав в тому, що 25 мільйонів зайнятого на той момент населення в світі могли залишитися без роботи, як результат впливу карантинних обмежень. Це на 3 мільйони більше ніж, за глобальної фінансової кризи 2008-2009 років, де кількість людей, що втратили роботи внаслідок кризи становила 22 мільйони. Другий варіант розвитку подій на ринку праці є кращий, відповідно до нього, кількість осіб, що можуть залишитися без роботи мають становити 13 мільйонів. Третій варіант є найоптимальніший i відповідно до нього число осіб, які можуть втратити роботу становитиме 5,3 мільйони. Проте розвиток подій на світовому ринку праці за останніми двома варіантами можливий тільки за умови, що уряд країн буде вести чітку політику щодо цього питання. [16]

Якщо розглядати ринок праці в період карантинних обмежень на прикладі України, то рівень безробіття почав підвищуватись у квітні, із запровадженням жорстких заходів карантину. У березні кількість безробітних в Україні становила 349 тис. осіб, то у квітні цей показник становив 457 тис., у травні 511 тис., а в червні 517 тис. осіб. I лише в липні цей показник зменшився до 506 тис., і в серпні - до 474 тисяч (Рис.1). [15] 


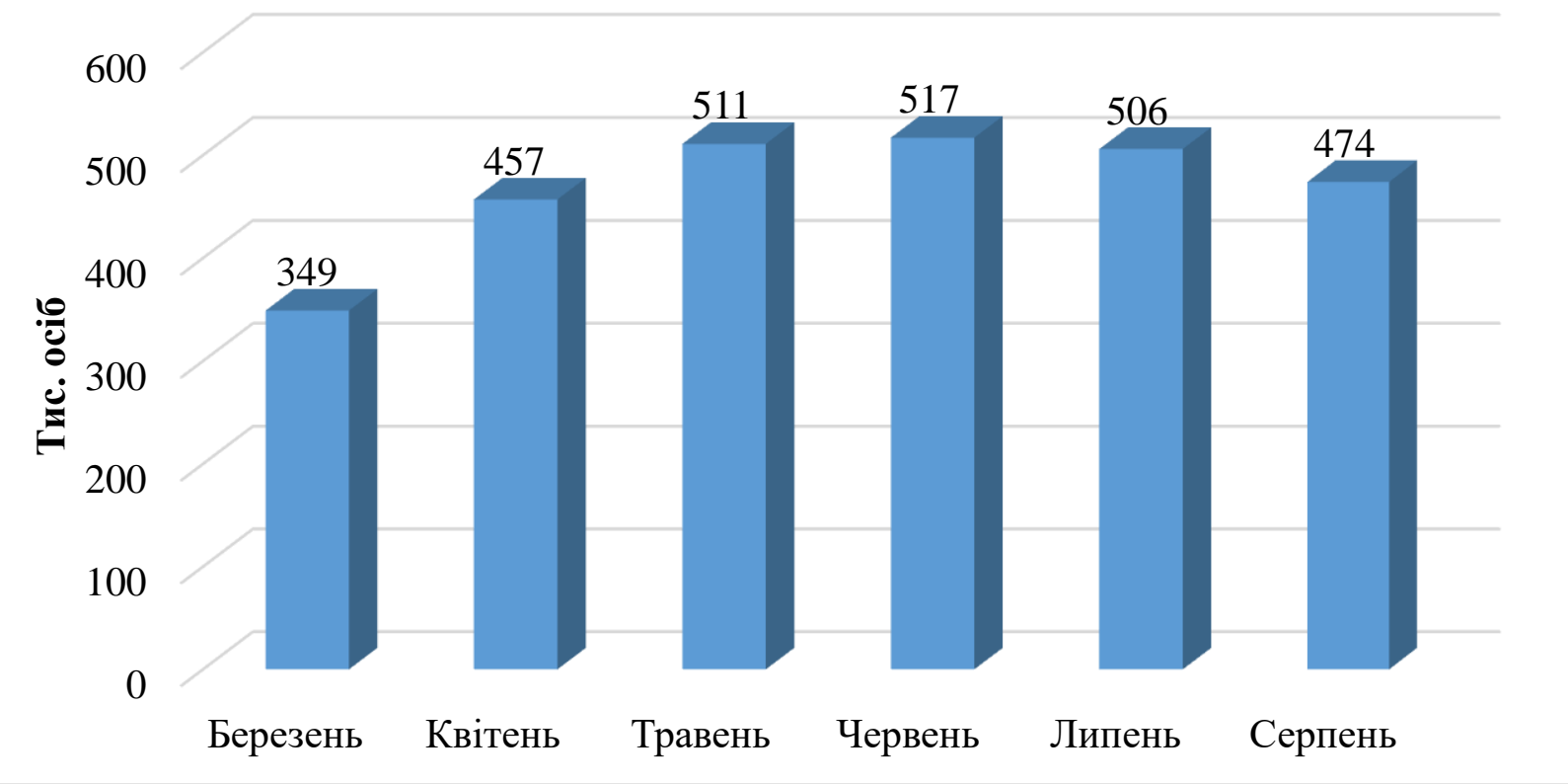

Рис. 1. Кількість безробітних в Україні за період із березня до серпня 2020 p.

Джерело: сформовано авторами на основі [15]

Загалом, у період пандемії в Україні кількість безробітних становить на 67\% більше, ніж за аналогічний період 2019 року. [15]

Такі масові скорочення робочих місць, розв'язуючи проблему підприємців зменшення витрат, спричиняють іншу проблему - ріст рівня безробіття в країні, яка $є$ не менш важливою. Тому керівництво держави закликає роботодавців використовувати різні можливі способи збереження робочих місць із відповідними особливостями оплати праці 3 одночасним дотриманням карантинних вимог. Законодавством України на період карантину для дотримання карантинних заходів рекомендується надати працівникам щорічної основної та додаткової відпустки, інших відпусток, що будуть оплачені або відпустки без збереження виплати заробітної плати; запровадження неповного чи скороченого робочого часу; організація позмінної або дистанційної роботи; запровадження простою. Запропоновані шляхи дотримання карантинних заходів мають свої особливості оплати праці. [10] 
Якщо розглядати питання відпусток, то працівники мають право отримати щорічну основну відпустку, безоплатну відпустку або інший вид відпустки передбачений законодавством або трудовим договором. Відпустка під час карантину може надаватися за погодженням працівника й роботодавця, як самого факту надання відпустки так і термінів іï надання, за умови, якщо відсутність працівника не відобразиться на роботі підприємства. [3]

На період карантину працівники частіше почали користуватися своїм правом на отримання відпустки без збереження заробітної плати, тому під час карантину кількість днів у відпустці без збереження зарплати не включається у загальний строк 15 днів, встановлений для цього виду відпусток, тобто працівник може отримати таку відпустку на увесь період карантину. Для отримання такої відпустки працівнику необхідно написати заяву, а роботодавцю видати на іiі підставі відповідний розпорядчий документ. У разі продовження карантину працівникам знову необхідно буде писати заяву про надання відпустки, а роботодавцю - видавати наказ. У заяві та наказі про відпустку може бути передбачене автоматичне продовження відпустки, якщо карантин буде продовжено. Оплата періоду перебування у безоплатній відпустці однозначно не здійснюється, а от чи потрібно сплачувати ССВ залежить від деяких чинників, тому для того, щоби визначити розмір і обов’язковість сплати ЄСВ користуємось алгоритмом (Рис. 2.). [4] 


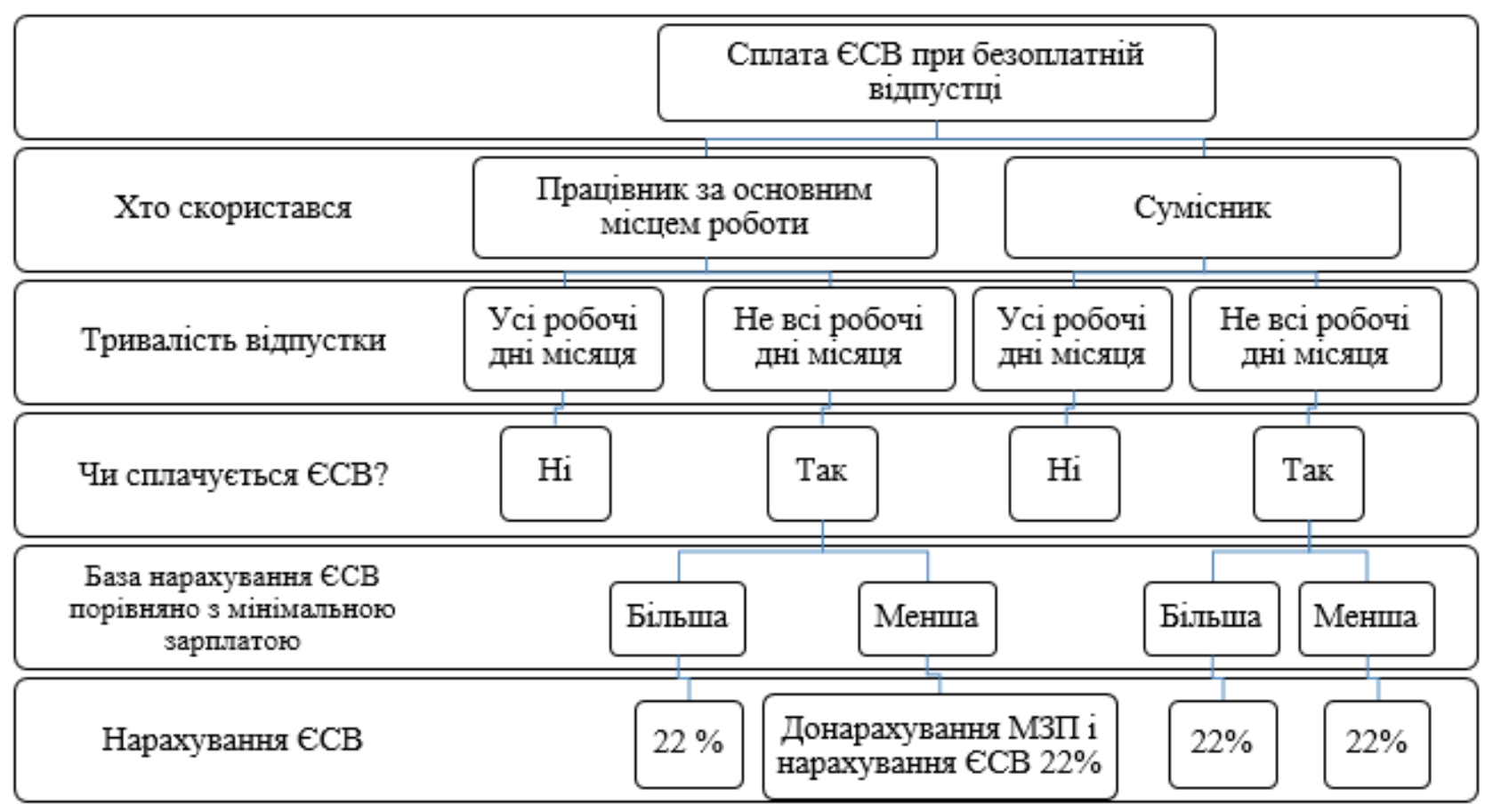

Рис. 2. Алгоритм визначення розміру сплати ССВ за місяць у якому працівник перебував у безоплатній відпустці

Джерело: створено авторами на основі [4]

Переведення працівника на роботу в умовах неповного робочого часу проводиться після попередження працівника не пізніше ніж за два місяці про дані зміни та за його згодою, що документується заявою працівника шодо встановлення йому неповного робочого часу. У цій заяві повинно бути зазначено вид неповного робочого часу; режим роботи за неповного робочого часу; період на який встановлюється неповний робочий час. Після написання заяви, оформляється наказ по підприємству. За почасової системи оплаті праці, оплата праці проводиться за фактично відпрацьований час відповідно до табелю обліку робочого часу. За відрядної системи оплаті праці - за фактично виконану роботу за відрядними розцінками. Обсяг виконаної працівником роботи відображається у нарядах на виконання робіт. [7]

Оплата позмінної роботи зазвичай здійснюється за почасовою системою оплати праці. Понаднормові години виявляються вкінці облікового періоду на 
основі списку осіб, що працювали, список заповнюється в одному примірнику й передається до бухгалтерії. Ці години оплачуються в подвійному розмірі, компенсація через надання відгулу не допускається. Доплата за понаднормову роботу в неробочі та святкові дні не передбачається. Робота в нічний час оплачується в підвищеному розмірі, але не нижче 20 \% тарифної ставки. [6]

Що стосується дистанційної роботи, то така форма може запроваджуватися після погодження 3 працівниками. Потім видається відповідний наказ та проводиться ознайомлення з ним працівників. Якщо запроваджено дистанційну роботу, то посада та зарплата повинні бути збережені. Роботодавець зобов'язаний забезпечити вірний облік робочого часу чи обсягу виконаної роботи, використовуючи всі можливі методи, які погоджені з працівниками. Оплата має здійснюватися не рідше двох разів на місяць 3 інтервалом не більше 16 календарних днів і не пізніше 7 днів після закінчення періоду. [5]

Працівники, що користуються власними засобами для роботи, можуть отримати компенсацію за їх зношування. Розмір та порядок надання компенсаційних виплат визначаються роботодавцем після обговорення 3 працівником. Працівник, також, може розраховувати на часткову компенсацію витрат за використання електроенергії та води, зв'язку та обслуговування обладнання. [11]

Якщо ж підприємство вирішило запровадити простій, то в цей період оплата праці здійснюється з розрахунку не менше від 2/3 ставки чи окладу або відповідно до розміру передбаченого колективним договором. Упродовж простою нарахування доплат і надбавок не здійснюються, через те, що в цей період працівники не можуть виконувати встановлену норму. Податки 3 нарахованої заробітної плати під час запровадженого простою роботодавець мусить сплатити за загальним правилом. Тимчасова непрацездатність працівника, що розпочалась до запровадження простою чи під час простою і триває після його закінчення, оплачується на загальних підставах. [10, с. 95] 
Вчені досліджуючи дані проблеми вносили різні пропозиції щодо удосконалення обліку розрахунків оплати праці за різних умов діяльності підприємств ( таблиця 1).

\section{1. Погляди вчених щодо удосконалення обліку розрахунків оплати праці} за різних умов

\begin{tabular}{|l|c|}
\hline \multicolumn{1}{|c|}{ Автор } & \multicolumn{1}{|c|}{ Пропозиція } \\
\hline Шульга Н.В. & \multicolumn{1}{|c|}{ Запропонувала удосконалити методику обліку за допомогою } \\
уточнення форми і структури про надання оплачуваних відпусток та \\
відомостей розрахунку оплати відпусток, які необхідні для \\
правильності та достовірності розрахунків оплати праці та виплат \\
пов'язаних з ними податків. [14, с. 18]
\end{tabular}

Джерело: сформовано авторами на основі $[11,12,13,14,15]$

Однак, майже відсутні дослідження, які дають змогу обрати оптимальні варіанти оплати праці працівників за умов форс мажорних обставин, що були б сприятливими, як для роботодавців так і для працівників.

Використовуючи таблицю 2 узагальнимо інформацію щодо особливостей здійснення розрахунків з оплати праці під час пандемії в зарубіжних країнах.

\section{2. Шляхи рішення питання розрахунків з оплати праці в зарубіжних}

\section{країнах}

\begin{tabular}{|c|c|c|}
\hline Країна & Захід & Мета заходу \\
\hline Польща & $\begin{array}{l}\text { Зміна графіку роботи; дозвіл понаднормової } \\
\text { роботи. } \\
\text { Для оплати праці штатних працівників } \\
\text { передбачена терміном до } 3 \text { місяців допомога, розмір } \\
\text { якої становить } 50 \% \text { іх загальної винагороди. }\end{array}$ & $\begin{array}{cr}\text { Не } & \text { допустити } \\
\text { зупинку } & \text { діяльність } \\
\text { підприємств. } & \\
\text { Підтримати } & \text { малі } \quad \text { й } \\
\text { середні } & \text { підприємства } \text { та }\end{array}$ \\
\hline
\end{tabular}




\begin{tabular}{|c|c|c|}
\hline & & $\begin{array}{l}\text { зберегти на них робочі } \\
\text { місця. }\end{array}$ \\
\hline Болгарія & $\begin{array}{l}\text { Запровадження програми «Міра } 60 / 40 » . \\
\text { Відповідно до цієї програми, держава бере на себе } \\
\text { покриття } 60 \% \text { суми доходу } 3 \text { соціального } \\
\text { забезпечення терміном до } 3 \text { місяців, решту } 40 \% \\
\text { сплачує роботодавець. } \\
\text { Дозвіл роботодавцю в односторонньому } \\
\text { порядку неповний робочий час терміном не більше } \\
3 \text { місяців та надавати оплачувану щорічну відпустку } \\
\text { без згоди працівника терміном до } 10 \text { днів. }\end{array}$ & $\begin{array}{l}\text { Підтримка } \\
\text { роботодавців. }\end{array}$ \\
\hline Італія & 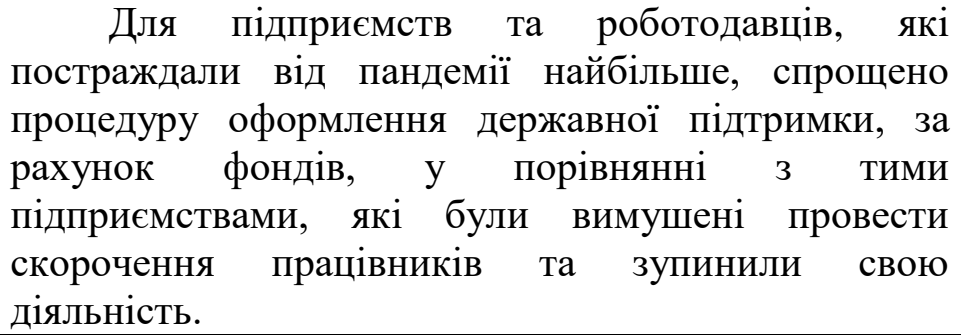 & \begin{tabular}{l}
\multicolumn{2}{c}{ Підтримка } \\
підприємств, що \\
найбільше постраждали \\
від пандемії.
\end{tabular} \\
\hline $\begin{array}{l}\text { Велика } \\
\text { Британія }\end{array}$ & $\begin{array}{l}\text { Програмну компенсацію роботодавцям до } 80 \% \\
\text { затрат на утримання працівників, які знаходяться у } \\
\text { вимушеній відпустці через COVID-19. } \\
\text { Працівники, які працюють у декількох } \\
\text { роботодавців, дозволено бути у вимушеній } \\
\text { відпустці за кожним } 3 \text { місць роботи отримувати } \\
\text { допомогу за кожним з них. }\end{array}$ & \begin{tabular}{l}
\multicolumn{1}{c}{ Державна підтримка } \\
роботодавців \\
підтримання \\
рівня працансового \\
рівників.
\end{tabular} \\
\hline Канада & $\begin{array}{l}\text { Роботодавці мають право на субсидію за } \\
\text { умови підтвердженої втрати доходів більше ніж на } \\
\text { 30\%. Субсидія надається тільки якщо працівник } \\
\text { знаходиться в оплачуваній відпустці та за умови, } \\
\text { що за цей період він отримує від роботодавця } \\
\text { винагороду, але не виконує роботи. }\end{array}$ & $\begin{array}{l}\text { Підтримка } \\
\text { роботодавців, які суттєво } \\
\text { зменшили рівень доходу, } \\
\text { у зв’язку } 3 \text { карантинними } \\
\text { заходами }\end{array}$ \\
\hline $\begin{array}{l}\text { Сполучені } \\
\text { Штати } \\
\text { Америки }\end{array}$ & \begin{tabular}{l}
\multicolumn{2}{c}{ Держава не зобов’язує компанії оплачувати } \\
відпустки чи лікарняні. Покриття компенсації \\
безробітнім відбувається через \\
страхування. Рішення щодо виплат залишається за \\
компанією.
\end{tabular} & $\begin{array}{c}\text { Підтримка } \\
\text { підприємців }\end{array}$ \\
\hline
\end{tabular}

Джерело: сформовано авторами на основі [2]

3 огляду на досвід зарубіжних країн, щодо питання розрахунків з оплати праці в період карантинних обмежень, можемо зробити такі пропозиції. Зокрема, доцільно буде дозволити на офіційних підставах понаднормову роботу. Цей захід 
можна впровадити у сферах, де дистанційна робота $є$ ефективною. Оплату здійснювати, як за понаднормові відпрацьовані години чи обсяг виготовленої продукції. Проте цей захід на підприємствах можна впроваджувати лише за попереднього погодження 3 працівниками. Запропонований захід спрямований на підтримку, як працівників, так і роботодавців, оскільки дає змогу роботодавцю ефективніше використовувати працю, а працівникам отримувати відповідну плату.

У ситуації, яка склалася, для точності ведення обліку робочого часу доречно використовувати електронну основу відслідковування діяльності працівників, за попереднім погодженням із працівниками. Для деталізації обліку можна відкрити аналітичні рахунки, на яких буде відображатися інформація розрахунків із працівниками по виплатах, які характерні лише на період карантину. Зокрема, доцільно запровадити окремий аналітичний рахунок для компенсаційних витрат, що надається під час дистанційної роботи за використання власних засобів для роботи та деяке відшкодування за оплату комунальних послуг.

Для обліку розрахунків 3 оплати праці доцільно також деталізувати інформацію під час документування цих операцій. За необхідності, керівник повинен видавати відповідні накази, щодо змін на підприємстві пов'язаних із трудовою діяльністю із зазначенням відповідної інформації. У розрахунковоплатіжній відомостях зазначати детальну інформацію щодо виплат, які здійснюються. У журналах-ордерах здійснювати деталізацію за відповідними рахунками. У табелі обліку робочого часу зазначати детальну інформацію щодо умов роботи за яких працює працівник (неповний робочий час, позмінна робота, дистанційна робота), причину відсутності (самоізоляція, COVID-19, інше захворювання, простій на підприємстві), вид відпустки (основна, додаткова, за власний рахунок).

Оскільки, у період карантину працівники частіше користуються своїм правом на відпустку, тобто відбувають майже всі належні для них дні відпустки, а також отримують безоплатну відпустку, то контроль використаних і невикористаних 
днів відпустки має значне місце в роботі бухгалтерської служби. Для полегшення контролю, доцільно буде використовувати таку форму внутрішньогосподарської звітності підприємства (таблиця 3).

\section{3. Відомість використаних та невикористаних відпусток працівниками}

\begin{tabular}{|c|c|c|c|c|c|c|c|c|}
\hline & ПІП, посада & Може бу & и надана & & адана відпу & тка & & \\
\hline & & & & & & Да & & : \\
\hline 这 & Вид відпустки & $\begin{array}{l}\text { Кількість } \\
\text { календ. } \\
\text { днів }\end{array}$ & $\begin{array}{c}\text { Період, за } \\
\text { який } \\
\text { надається } \\
\text { відпустка }\end{array}$ & $\begin{array}{c}\text { Кількість } \\
\text { календ. } \\
\text { днів }\end{array}$ & $\begin{array}{c}\text { Період, за } \\
\text { який } \\
\text { надається } \\
\text { відпустка }\end{array}$ & 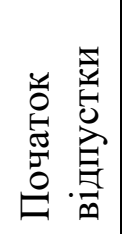 & 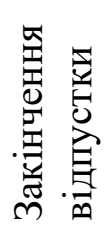 & 迹 \\
\hline & Щорічні відпустки: ... & & & & & & & \\
\hline & $\begin{array}{l}\text { Додаткова відпустка у } \\
\text { зв'язку з навчанням: .. }\end{array}$ & & & & & & & \\
\hline & Творча відпустка: ... & & & & & & & \\
\hline & Соціальна відпустка: . & & & & & & & \\
\hline & $\begin{array}{l}\text { Відпустка без } \\
\text { збереження заробітної } \\
\text { плати: ... }\end{array}$ & & & & & & & \\
\hline & $\begin{array}{l}\text { Інша відпустка } \\
\text { передбачена трудовим } \\
\text { договором: ... }\end{array}$ & & & & & & & \\
\hline
\end{tabular}

Джерело: сформовано авторами

Дана форма має заповнюватися, як по кожному працівнику окремо, (оскільки працівники мають право на різні види відпусток), так і зведена по господарюючому суб'єкту. Крім того, деякі види відпусток, якщо вони невикористані упродовж року, працівник має право використати в наступних роках. Дана форма дає змогу вести облік днів відпусток наростаючим підсумком по роках. Чіткий облік днів відпусток є важливим, оскільки прямо впливає на розмір виплат під час звільнення.

Висновки i перспективи. Підсумовуючи викладений матеріал, можна зробити висновок, що пандемія значно зменшила кількість робочих місць та 
негативно позначилося як на бізнесі, так i на економіці країн загалом. Для зменшення темпів росту рівня безробіття рекомендовано запровадження різних особливостей трудової діяльності підприємцями для працівників. Деталізація розрахунків 3 оплати праці в умовах карантину, вимагає внесення змін до первинних та зведених форм документів, що дозволить здійснювати оперативну аналітичну оцінку статей витрат та питомої ваги витрат на оплату праці в загальному обсязі витрат. Внесені пропозиції, щодо використання господарюючими суб’єктами «Відомості використаних та невикористаних відпусток працівниками» забезпечить інформацію про види відпусток та їх використання в розрізі працівників та загалом на підприємстві та дасть змогу вести облік днів відпусток наростаючим підсумком за роками. Сформована інформація дасть змогу розмежувати розрахункові операції та забезпечить, як оперативні, так зведені інформаційні потоки під час формування статистичної, фінансової та управлінської звітності для користувачів різних рівнів управління.

\section{Список використаних джерел}

1. Гуцаленко Л.В., Ніколенко М.С. Особливості обліку оплати праці в період простою. Облік, оподаткування, контроль та аналіз в активізації діяльності економічних суб'єктів: зб. матеріалів 75-ї Всеукр. наук.-прак. конф. Київ: НУБіПУ, 2020. С. 94-96.

2. Очеретько Л.М., Удовиченко Г.І. Удосконалення обліку заробітної плати на підприємстві. Ефективна економіка. №12. 2020 URL: http://www.economy.nayka.com.ua/pdf/12

3. Види відпусток. Протокол: веб-сайт. URL: https://protocol.ua/ua/pro_vidpustki_stattya_4/ (дата звернення: 17.11.2020).

4. Відпустка-2020 після карантинної (не)роботи. Бухгалтер: веб-сайт. URL: $\quad$ https://buhgalter.com.ua/articles/kadrova-sprava/vidpustka-2020-pislyakarantinnoyi-neroboti/ (дата звернення: 19.11.2020).

5. Дистанційна робота: які правила оплати праці? Дебет-Кредит: вебсайт. URL: https://news.dtkt.ua/labor/compensation/62993 (дата звернення: 24.12.2020).

6. Змінний графік роботи. Бухоблік: веб-сайт. URL: https://www.buhoblik.org.ua/kadry-zarplata/vremya/2714-zminnij-grafik-roboti.html\#05 (дата звернення: 19.11.2020). 
7. Карантин: оплата праці у разі переведення на неповний робочий день. Лігазакон: веб-сайт. URL: https://biz.ligazakon.net/news/199609_karantin-oplataprats-u-raz-perevedennya-na-nepovniy-robochiy-den (дата звернення: 19.11.2020).

8. Колосок А.М. Шляхи вдосконалення організації обліку оплати праці на підприємстві. Науковий вісник Волинського державного університету імені Лесі Українки. 2011. № 4. С.129-137.

9. Мельник Т.Г. Облік, аналіз та аудит праці і її оплати. автореф. дис. канд. екон. наук за спец. 08.06.04 Бухгалтерський облік, аналіз та аудит / Т.Г.Мельник. - К.:, 2006. - 12 с.

10. Робота в умовах карантину: оплата, відпустки, режими. Вісник: вебсайт. URL: http:/www.visnuk.com.ua/uk/news/100019937-robota-v-umovakhkarantinu-oplata-vidpustki-rezhimi (дата звернення: 17.11.2020).

11. Роз'яснення щодо дистанційної роботи в умовах карантину. Ibuhgalter: веб-сайт. URL: https://ibuhgalter.net/news/11450 (дата звернення: 24.12.2020).

12. Суліменко Л.А, Киян А.В, Вітер С.А. Облік і аналіз розрахунків 3 оплати праці. Науково-практичний журнал «Бухгалтерський облік, аналіз та аудит». 2018. Вип.29. С.395-404.

13. Штик Ю.В. Бухгалтерський облік винагород працівникам торгівельновиробничих підприємств. автореф. дис. канд. екон. наук за спец. Бухгалтерський облік, аналіз та аудит (за видами економічної діяльності) / Ю.В.Штик.

14. Шульга Н.В. Облік і аудит розрахунків 3 оплати праці та аналіз ефективності використання трудових ресурсів: автореф. дис. канд. екон. наук за спец. 08.00.09 Бухгалтерський облік, аналіз та аудит (за видами економічної діяльності) / Н.В. Шульга. - К.:, 2008. - 18 с.

15. Як пандемія COVID-19 змінила ринок праці в Україні. Укрінформ: веб-сайт. URL: https://www.ukrinform.ua/rubric-society/3104312-ak-pandemiacovid19-zminila-rinok-praci-v-ukraini.html (дата звернення: 23.12.2020).

16. Coronavirus Crisis Risks Causing 25 Million Global Job Losses. Bloomberg: веб-сайт. URL: https://www.bloomberg.com/news/articles/2020-03-18/coronavirus-crisisrisks-causing-25-million-global-job-losses (дата звернення: 23.12.2020).

\section{References}

1. Gutsalenko L.V, Nikolenko M.S Features of payroll accounting during downtime. Accounting, taxation, control and analysis in the intensification of economic entities: Coll. materials of the 75th All-Ukrainian. scientific-practical conf. Kyiv: NUBiPU, 2020. S. 94-96.

2. Ocheretko LM, Udovichenko GI Improving payroll accounting at the enterprise. Efficient economy. №12. 2020 URL: http://www.economy.nayka.com.ua/pdf/12
3.Types
of vacations.
Protocol:
website.
URL: https://protocol.ua/ua/pro_vidpustki_stattya_4/ (access date: 17.11.2020). 
4. Vacation-2020 after quarantine (non) work. Accountant: website. URL: https://buhgalter.com.ua/articles/kadrova-sprava/vidpustka-2020-pislya-karantinnoyineroboti/ (access date: 19.11.2020).

5. Remote work: what are the rules of remuneration? Debit Credit: website. URL: https://news.dtkt.ua/labor/compensation/62993 (access date: 24.12.2020).

6. Variable work schedule. Accounting: website. URL: https://www.buhoblik.org.ua/kadry-zarplata/vremya/2714-zminnij-grafik-roboti.html\#05 (access date: 19.11.2020).

7. Quarantine: remuneration in case of transfer to part-time work. League Law: website. URL: https://biz.ligazakon.net/news/199609_karantin-oplata-prats-u-razperevedennya-na-nepovniy-robochiy-den (access date: 19.11.2020).

8. Kolosok AM Ways to improve the organization of payroll accounting at the enterprise. Scientific Bulletin of Volyn State University named after Lesya Ukrainka. 2011. № 4. P.129-137.

9. Melnik TG Accounting, analysis and audit of labor and its payment. author's ref. dis. Cand. econ. science for special. 08.06.04 Accounting, analysis and audit / TG Melnyk. - K.:, 2006. - 12 c.

10. Work in quarantine conditions: payment, holidays, regimes. Bulletin: website. URL: $\quad$ http://www.visnuk.com.ua/uk/news/100019937-robota-v-umovakh-karantinuoplata-vidpustki-rezhimi (access date: 17.11.2020).

11. Explanation of remote work in quarantine. Ibuhgalter: website. URL: https://ibuhgalter.net/news/11450 (access date: 24.12.2020).

12. Sulimenko LA, Kiyan AV, Viter SA Accounting and analysis of payroll. Scientific and practical journal "Accounting, analysis and audit". 2018. Issue 29. P.395404.

13. Shtyk Yu.V. Accounting for remuneration of employees of trade and manufacturing enterprises. author's ref. dis. Cand. econ. science for special. Accounting, analysis and audit (by types of economic activity) / Yu.V. Shtyk.

14. Shulga NV Accounting and audit of payroll calculations and analysis of the efficiency of labor resources: author's ref. dis. Cand. econ. science for special. 08.00.09 Accounting, analysis and audit (by type of economic activity) / NV Shulga. - K.:, 2008. $18 \mathrm{c}$.

15. How the COVID-19 pandemic changed the labor market in Ukraine. Ukrinform: website. URL: https://www.ukrinform.ua/rubric-society/3104312-akpandemia-covid19-zminila-rinok-praci-v-ukraini.html (access date: 23.12.2020).

16. Coronavirus Crisis Risks Causing 25 Million Global Job Losses. Bloomberg: website. URL: https://www.bloomberg.com/news/articles/2020-03-18/coronaviruscrisis-risks-causing-25-million-global-job-losses (accessed 23.12.2020). 


\title{
PECULIARITIES OF ACCOUNTING OF PAYMENT CALCULATIONS IN A PANDEMIC CONDITION
}

\author{
L. Gutsalenko, M. Nikolenko \\ National University of Life and Environmental Sciences of Ukraine, Kyiv, Ukraine
}

\begin{abstract}
The article considers the forecast of the International Labor Organization on the unemployment rate caused by the COVID-19 pandemic. The real indicators of unemployment in Ukraine in terms of months during the introduced quarantine in 2020 are analyzed and these data are compared with the indicators for the same period in 2019. The main possible ways of preserving jobs with compliance with quarantine measures, as well as minimizing labor costs and maintaining the level of productivity. Each of the methods listed in the article is described. Emphasis is placed on the peculiarities of their documentation at enterprises. The accounting of payroll calculations under different conditions during quarantine has been studied. In particular, a detailed study of the payment of various types of leave during quarantine, their documentation and conditions of granting. Particular attention is paid to the provision of free vacations, its duration and features of extension. The issue of accrual of the Unified social contribution when granting an employee vacations without pay is considered. The peculiarities of payment of part-time employees and employees transferred to shift work during quarantine are compared. Peculiarities of overtime pay for hourly forms of payment have been studied. Remuneration for remote work and the the regime under which the performance of official duties may be performed are analyzed. The possibility of providing employees with other benefits for work is considered. Possible payments to employees, and also features of accrual and payment of taxes during downtime are highlighted. The views of scientists on this subject are analyzed. The experience of other countries on the issue of payment in a pandemic is considered. Suggestions are given on possible measures and details of accounting for payroll during the quarantine period. The form of the internal economic reporting for control of the used and unused days of vacations is offered. Conclusions are made on the information presented in the article.
\end{abstract}

Key words: accounting, wages, working hours, paid vacation, unpaid vacation, distance work. 